\title{
RADIOCARBON DATING IN THE SOVIET UNION ${ }^{1}$
}

\section{S. V. BUTOMO}

This report covers the investigations of the Laboratory of Archeological Technology of the Institute of Archeology of the Academy of Sciences of the U.S.S.R. under the technical direction of Corresponding Academician I. Ye. Starik. This work was begun in 1956, but the bulk of the dates were obtained during 1959-61 by the ethyl-benzol technique. For a control, ethyl-benzol was synthesized from the annual rings of the heartwood of an 80-yr-old larch. Depending on the size of the sample submitted for analysis, from $15.70 \mathrm{ml}$ of ethyl-benzol was used.

Archaeologic samples clearly dated from a Scythian kurgan in the Altai uplands were given radiocarbon analysis to check the $\mathrm{C}^{14}$ laboratory techniques. The following dates were obtained:

\begin{tabular}{|c|c|c|c|c|}
\hline No. & Specimen & Submitted & Notes & Date $^{2}$ (в.P.) \\
\hline 1 & RUL-120 & S. I. Rudenko & $\begin{array}{l}\text { Beam from covering of } \\
\text { Pazyryk Kurgan II, Altai }\end{array}$ & $\begin{array}{r}2350 \pm 140 \\
{[400 \text { B.c. }]}\end{array}$ \\
\hline 2 & RUL-151 & S. I. Rudenko & $\begin{array}{l}\text { Part of covering of } \\
\text { Pazyryk Kurgan V, Altai }\end{array}$ & $\begin{array}{r}2440 \pm 50 \\
{[490 \text { B.c. }]}\end{array}$ \\
\hline 3 & RUL-132 & S. I. Rudenko & $\begin{array}{l}\text { Beam from covering of } \\
\text { Tuekta Kurgan }\end{array}$ & $\begin{array}{r}2450 \pm 120 \\
{[500 \text { B.c. }]}\end{array}$ \\
\hline 4 & RUL-129 & S. I. Rudenko & $\begin{array}{l}\text { Birch trunk from grave- } \\
\text { robber's shaft of Tuekta } \\
\text { Kurgan }\end{array}$ & $\begin{array}{r}2450 \pm 120 \\
{[500 \text { B.c. }]}\end{array}$ \\
\hline 5 & RUL-130 & S. I. Rudenko & $\begin{array}{l}\text { Beam from covering of } \\
\text { Katanda Kurgan }\end{array}$ & $\begin{array}{r}2420 \pm 130 \\
{[470 \text { в.c. }]}\end{array}$ \\
\hline 6 & RUL-293 & M. P. Griaznov & $\begin{array}{l}\text { Part of covering of } \\
\text { Shibe Kurgan }\end{array}$ & $\begin{array}{r}2420 \pm 100 \\
{[470 \text { B.c. }]}\end{array}$ \\
\hline
\end{tabular}

On the basis of archaeologic evidence, the Scythian kurgans above belong to the VI-IV centuries B.c. (2550-2350 B.P.), dates which agree with those determined by $\mathrm{C}^{14}$ analysis. The coincidence of the ages of RUL-132 and RUL129 indicates that the Tuekta Kurgan was plundered shortly after completion.

The choice of samples was related to other methodological laboratory problems, especially the establishment of the upper and lower limits of dating, the use of different organic substances for dating, etc. The earliest dates were obtained from Pleistocene and Holocene [Recent] geologic samples.

${ }^{1}$ Subm. by Henry Field and D. B. Shimkin, Harvard Univ.; extracted from p. 26-30 of S. I. Rudenko: Novyye metody $v$ arkheologicheskikh issledovaniyakh (New Methods in Archeological Investigations), Institut Arkheologiyi, Akademiya Nauk SSSR, Moscow, 1963. The techniques used are described in p. 9-26, 32-56.

${ }^{2}$ B.P. $=$ before present or absolute age before 1963. Brackets have been inserted to clarify the text. (D.B.S.) 


\begin{tabular}{|c|c|c|c|c|}
\hline No. & Specimen & Submitted & Notes & Date (B.P.) \\
\hline 7 & RUL-185 & V. N. Sukachev & $\begin{array}{l}\text { Wood from interglacial d } \\
\text { posits near Shurskol villa } \\
\text { Yaroslavl' Oblast }\end{array}$ & $\begin{array}{l}\text { de- }>45,000 \\
\text { lage, }\end{array}$ \\
\hline 8 & RUL-199 & V. N. Sukachev & $\begin{array}{l}\text { Wood from interglacial } \\
\text { deposits near Chere- } \\
\text { moshnik village, } \\
\text { Yaroslavl' Oblast }\end{array}$ & $\begin{array}{r}19,500 \pm 300 \\
{[17,550 \text { в.с. }]}\end{array}$ \\
\hline 9 & RUL-114 & V. N. Sukachev & $\begin{array}{l}\text { Wood from intergla- } \\
\text { cial deposits near } \\
\text { Levina Gora settlement, } \\
\text { Yaroslavl' Oblast }\end{array}$ & $\begin{array}{r}17,200 \pm 2500 \\
{[15,250 \text { B.C. }]}\end{array}$ \\
\hline 10 & RUL-197 & V. N. Sukachev & $\begin{array}{l}\text { Wood from intergla- } \\
\text { cial deposits near } \\
\text { Tutayevo, Yaroslavl' } \\
\text { Oblast }\end{array}$ & $\begin{array}{r}15,700 \pm 300 \\
{[13,750 \text { B.c. }]}\end{array}$ \\
\hline 11 & RUL-145 & V. A. Yakimovich & $\begin{array}{l}\text { Wood from cross-sec- } \\
\text { tion of second terrace } \\
\text { (Upper Pleistocene) } \\
\text { above Belaya River, } \\
\text { Bashkir ASSR }\end{array}$ & $\begin{array}{r}21,280 \pm 550 \\
{[19,330 \text { в.c. }]}\end{array}$ \\
\hline 12 & RUL-168 & V. N. Sukachev & $\begin{array}{l}\text { Wood from lower hori- } \\
\text { zons of Holocene [Re- } \\
\text { cent] deposit near } \\
\text { Gryamyachevo, Kaluga } \\
\text { Oblast }\end{array}$ & $\begin{array}{r}12,880 \pm 200 \\
{[10,930 \text { в.с. }]}\end{array}$ \\
\hline 13 & RUL-161 & V. N. Sukachev & $\begin{array}{l}\text { Wood from lower hori- } \\
\text { zons of Holocene de- } \\
\text { posits near Zvenigorod, } \\
\text { Moscow Oblast }\end{array}$ & $\begin{array}{r}15,080 \pm 270 \\
{[13,130 \text { в.c. }]}\end{array}$ \\
\hline 14 & RUL-205 & V. N. Sukachev & $\begin{array}{l}\text { Wood from Holocene } \\
\text { deposits near Debo- } \\
\text { lovskoye, Yaroslavl' } \\
\text { Oblast }\end{array}$ & $\begin{array}{r}12,800 \pm 900 \\
{[10,850 \text { в.c. }]}\end{array}$ \\
\hline
\end{tabular}

All the above data, excluding RUL-199, RUL-114 and RUL-197, are in general acord with geologic evidence.

The apparent juvenility of the wood samples from the interglacial deposits from the Cheremoshnik, Levina Gora and Tutayevo Rayons must be explained by the pollution of the specimens from the remains of the root-system of younger plants or by fractionation of carbon isotopes during the process of decay. Errors in the estimation of the geologic age of the samples are not excluded. ${ }^{3}$

The most recent wood samples are RUL-303, RUL-108 and RUL-172.

${ }^{3}$ It is also possible that these samples are interstadial within Würm rather than Riss-Würm interglacial. (D.B.S.) 


\begin{tabular}{|c|c|c|c|c|}
\hline No. & Sample & Submitted & Notes & Date (B.P.) \\
\hline 15 & RUL-303 & $\begin{array}{l}\text { Chernigov His- } \\
\text { torical Mus. }\end{array}$ & $\begin{array}{l}\text { Hollowed oak log boat from } \\
\text { cliff above Dniester } \\
\text { River, Chernigov Rayon. } \\
\text { Historically XII-XVIII } \\
\text { centuries }\end{array}$ & $\begin{array}{r}300 \pm 60 \\
{[\text { A.D. } 1650]}\end{array}$ \\
\hline 16 & RUL-108 & P. A. Rappaport & $\begin{array}{l}\text { Charred wood from } \\
\text { Kobylye gorodishche } \\
\text { [fortified settlement], } \\
\text { northwest USSR. Histori- } \\
\text { cally mid-XV century }\end{array}$ & $\begin{array}{l}660 \pm 120 \\
{[\text { A.D. } 1290]}\end{array}$ \\
\hline 17 & RUL-172 & $\begin{array}{l}\text { Vladivostok } \\
\text { Regional Mus. }\end{array}$ & $\begin{array}{l}\text { Part of wooden human } \\
\text { figurine (idol) from } \\
\text { Sergeyevka tumulus, Prim- } \\
\text { orskiy Kray, Far East. } \\
\text { Archaeologic date missing }\end{array}$ & $\begin{array}{r}780 \pm 65 \\
{[\text { A.D. } 1170]}\end{array}$ \\
\hline
\end{tabular}

Here attention must be called to the fact that $\mathrm{C}^{14}$ dating for samples less than $1000 \mathrm{yr}$ old is not as reliable as by other methods.

Two samples (RUL-179 and RUL-138) came from the Arctic and Antarctic; both were found on marine terraces. The ages give some clues as to the rapidity of their uplift.

\begin{tabular}{ccccc} 
No. Sample & Submitted & \multicolumn{1}{c}{ Notes } & Date (B.P.) \\
\hline 18 & RUL-179 & V. D. Dibner & $\begin{array}{l}\text { Fin (or flipper) from sur- } \\
\text { face of 10-m terrace, } \\
\text { southern coast, Zemlya } \\
\text { Aleksandra, Franz Josef } \\
\text { Archipelago }\end{array}$ & {$[250 \pm 90$} \\
19 & RUL-138 & E. S. Korotkevich & $\begin{array}{l}\text { Sea-elephant tissues from } \\
\text { surface of 25-m terrace, } \\
\text { Grierson Oasis, eastern } \\
\text { Antarctica }\end{array}$ & [A.D. 150]
\end{tabular}

The average uplift of these terraces, 2.5 and $14.0 \mathrm{~mm}$ per annum respectively, agrees well with the data obtained by other investigators.

The results of age determination of most of the archaeologic samples are given in the following table on p. 226. The data now available do not warrant general conclusions regarding their chronology relative to neighboring areas.

There are recent publications indicating that the value of $5568 \mathrm{yr}$ for the half-life for $\mathrm{C}^{14}$ is evidently too low and should be increased to $5720-5780 \mathrm{yr}$. This new value for the half-life leads us to an increase in the age of radiocarbon dates. However, all these dates, including those given here, are calculated from $\mathrm{T}_{\mathrm{C} 14}=5568 \mathrm{yr}$.

${ }^{4}$ Chernigov is on the Desna River. (H.F.) 


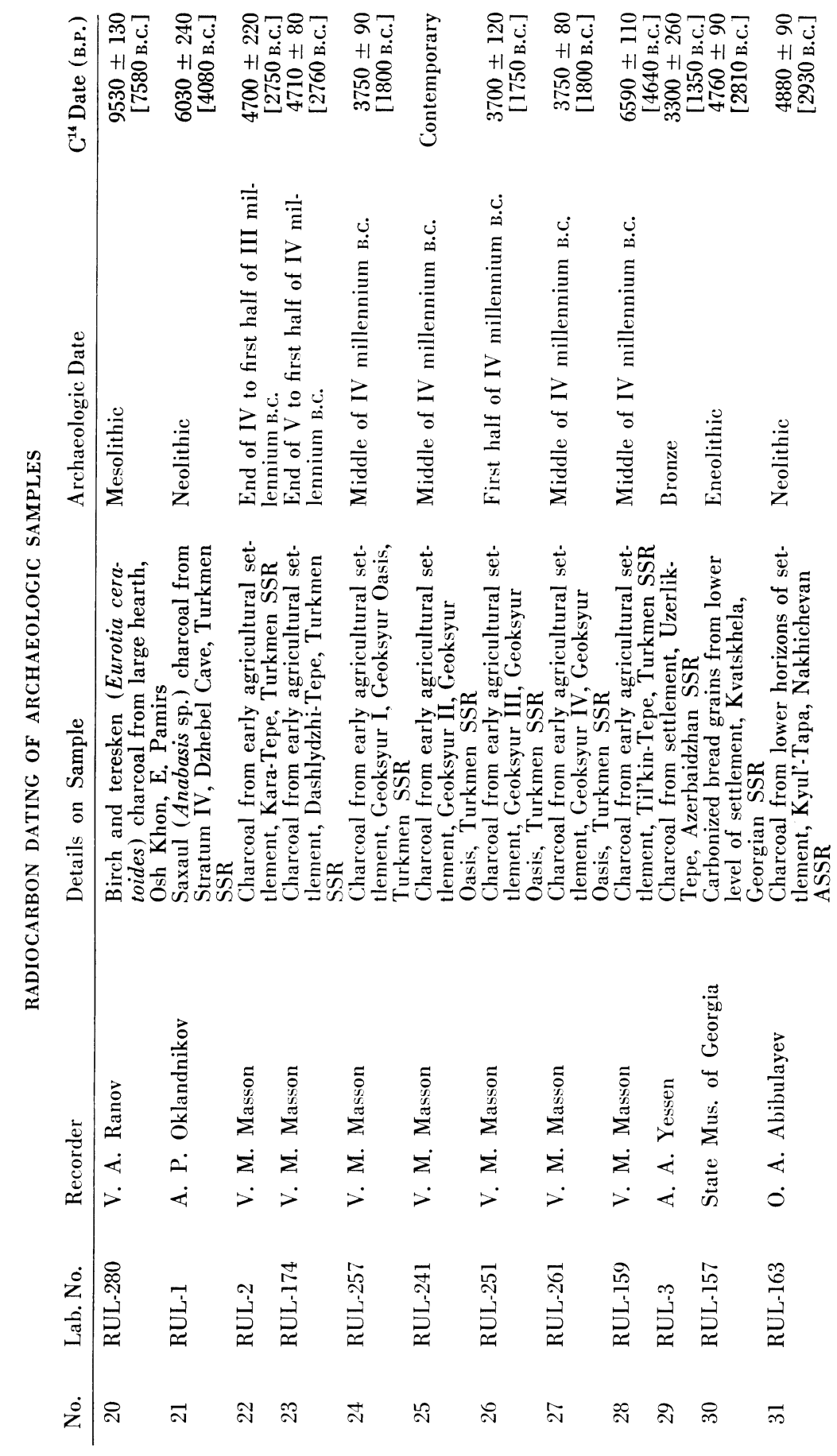




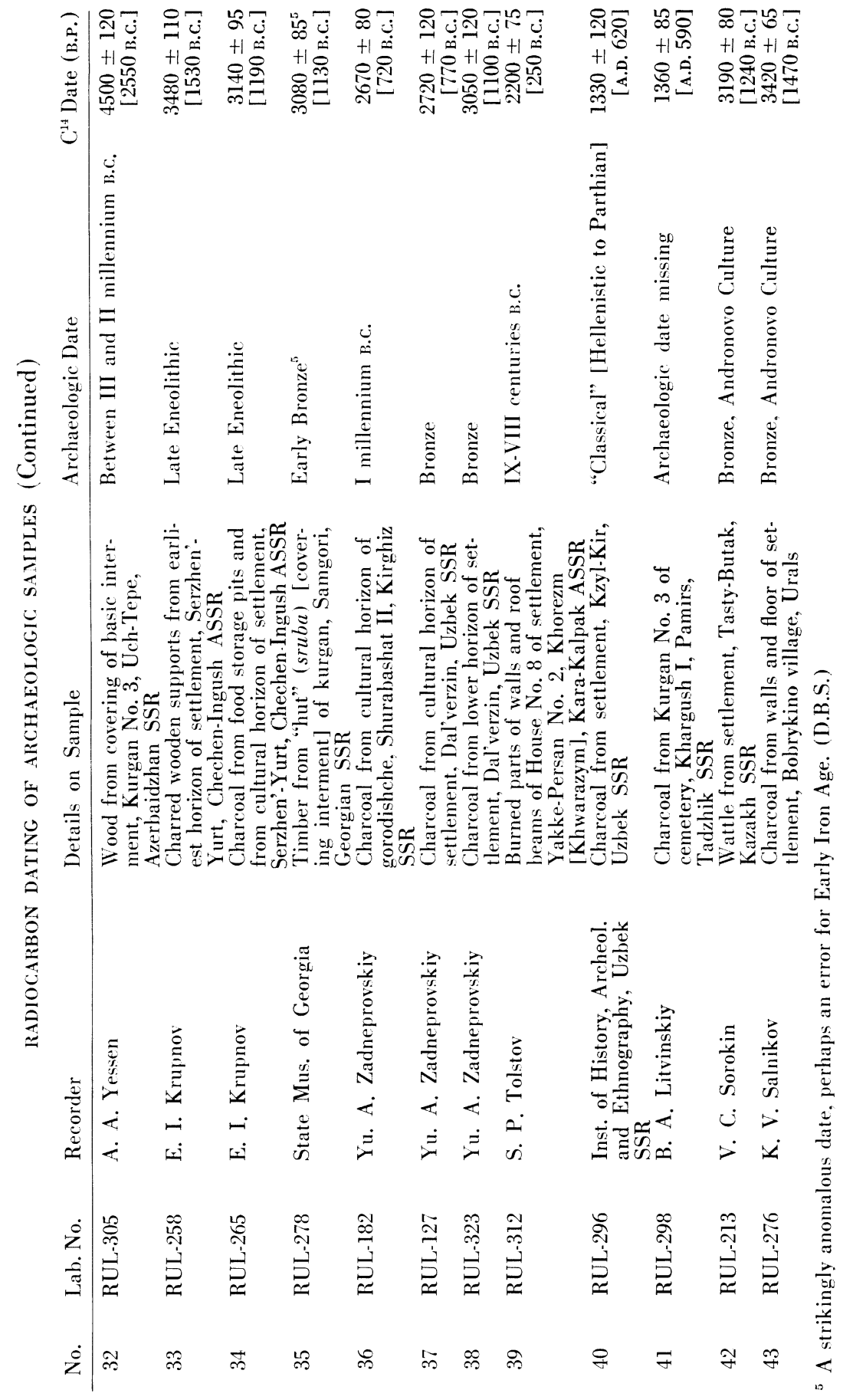




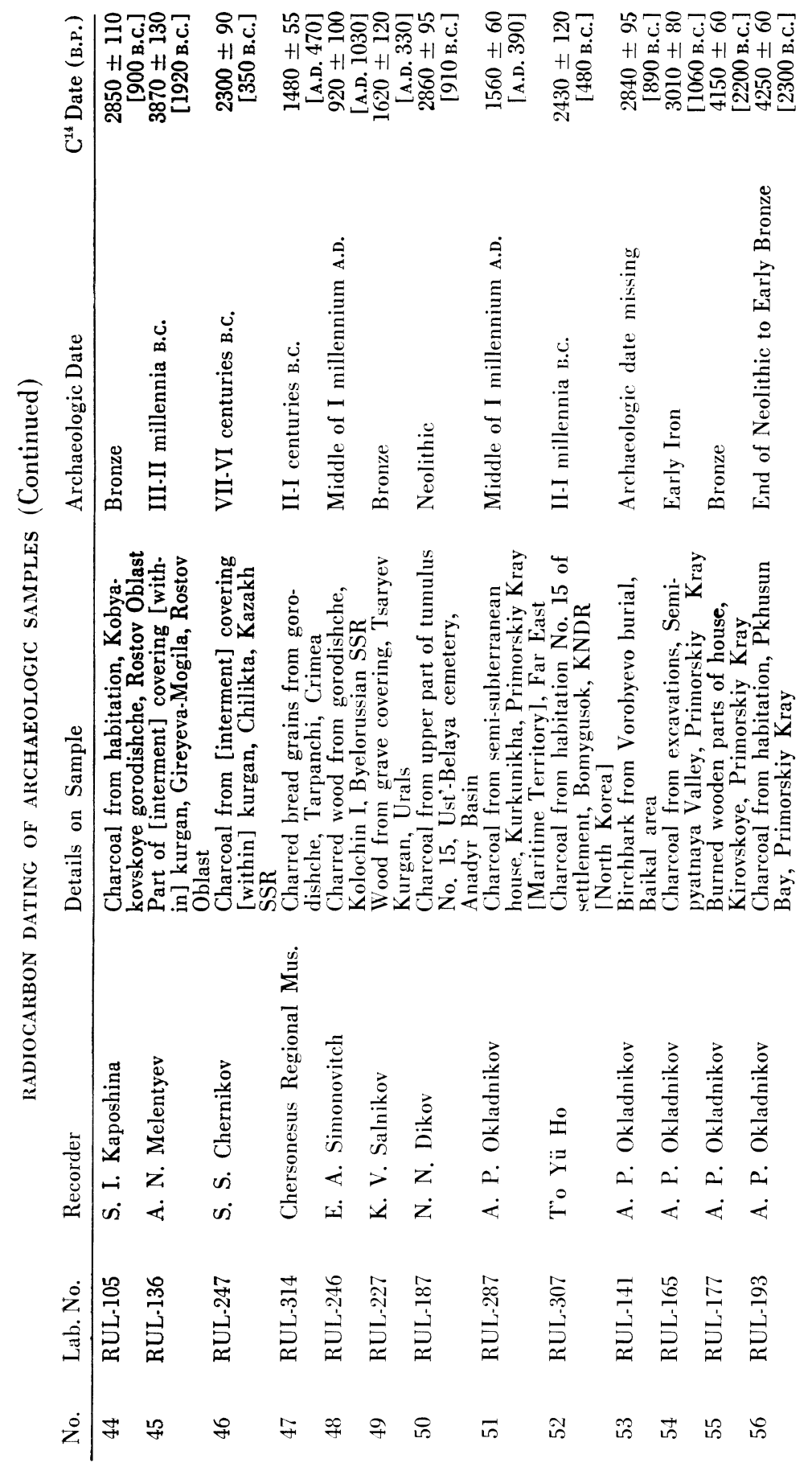

